\title{
Notas sobre a investigação e prova da criminalidade econômico-financeira organizada ${ }^{1}$
}

\author{
Notes on investigation and proofing \\ of the organized white-collar crime.
}

Diogo Malan

Professor Adjunto de Processo Penal da FND/UFRJ.

Doutor em Processo Penal pela USP. Advogado.

diogomalan@mirzamalan.com.br

Resumo: O presente estudo almeja analisar aspectos da investigação preliminar e da instrução processual no campo da chamada criminalidade econômico-financeira organizada, especialmente a partir do novo regramento introduzido pela Lei $12.850 / 13$. Assim, questionar-se-á a existência de peculiaridades do Direito Processual Penal aplicado à criminalidade econômico-financeira organizada, não só nos planos dogmático, legislativo e normativo, como também na própria dinâmica das práticas e procedimentos persecutórios adotados pelo sistema de administração da justiça criminal.

Palavras-chave: Processo Penal; investigação; prova; criminalidade econômico-financeira.

ABSTRACT: This study aims to analyze some aspects of the preliminary investigation and the trial in the field of organized economic and financial crime, especially in light of the Law 12.850/13. Thus, it will explore the existence of peculiarities of criminal procedure applied to organized economic and financial crime, not only in dogmatic, legislative and regulatory scopes, as well as in the dynamics of the practices and persecutory procedures adopted by the criminal justice administration system.

KEYWORDs: Criminal procedure; investigation; proof; White-collar crime.

1 O autor gostaria de agradecer de público ao Professor Nereu Giacomolli pelo privilégio da oportunidade de integrar o grupo de pesquisas Processo penal contemporâneo: Fundamentos, perspectivas e problemas atuais da PUC-RS, cujos instigantes debates serviram de inspiração para o presente artigo. Também agradeço ao amigo Renato Vieira pela gentileza da leitura de versão anterior do presente artigo. 


\section{INTRODUÇÃO}

O singelo objetivo do presente estudo é apontar algumas peculiaridades da investigação preliminar e da instrução processual no campo da chamada criminalidade econômico-financeira organizada.

Tal empreitada se revela oportuna, tendo em vista: (i) a recente entrada em vigor da Lei $\mathrm{n}^{\circ} .12 .850 / 13$, que "define organização criminosa e dispóe sobre a investigação criminal, os meios de obtenção da prova, infraçôes penais correlatas e o procedimento criminal'; (si) a enorme dificuldade em atingir, especialmente na seara da chamada criminalidade econômico-financeira organizada, a desejável concordância prática - na expressão de Jorge de Figueiredo Dias ${ }^{2}$ - entre as duas finalidades antitéticas do Direito Processual Penal: eficácia na realização da justiça e proteção dos direitos fundamentais do cidadão; (iii) a distância (muitas vezes abissal) que separa a doutrina do Direito Processual Penal aplicado à seara em estudo (Law in books) das práticas e procedimentos adotados pelo sistema de administração da justiça criminal na persecução desse tipo de criminalidade (Law in action).

Por questões de limitação de espaço e tempo, não se pretende fazer estudo dogmático aprofundado de nenhum instituto específico da Lei $\mathrm{n}^{\circ} .12 .850 / 13$ e tampouco aprofundar a fascinante discussão político-criminal acerca da legitimidade da supressão ou restrição de garantias processuais do acusado, como solução para a persecução eficaz da criminalidade grave (v.g. terrorismo, organizações criminosas etc.). ${ }^{3}$

2 FIGUEIREDO DIAS, Jorge de. O novo código de processo penal, In: Separata do Boletim do Ministério da Justiça, Lisboa, n. 369, pp. 05-23, 1987.

3 Para uma perspectiva crítica dessa corrente político-criminal, ver: BECK, Francis Rafael. Perspectivas de controle ao crime organizado e crítica à flexibilização de garantias. São Paulo: IBCCRIM, 2004; GIACOMOLLI, Nereu José. A garantia do devido processo legal e a criminalidade organizada, In: Revista de Estudos Criminais, Porto Alegre, n. 14, pp. 113121, 2004; GOMES FILHO, Antonio Magalhães. O crime organizado e as garantias processuais, In: Boletim do Instituto Brasileiro de Ciências Criminais, São Paulo, n. 21, p. 08, set. 1994; GOMES FILHO, Antonio Magalhães. Também em matéria processual provoca inquietação a Lei Anti-Crime Organizado, In: Boletim do Instituto Brasileiro de Ciências Criminais, São Paulo, n. 13, p. 01, fev. 1994; MALAN, Diogo. Processo 
Não obstante, é imprescindível enunciar a premissa político-criminal que norteará este estudo.

Trata-se da ideia de que o Direito Processual Penal é ramo do saber jurídico estruturado teórico-conceitualmente como um conjunto de técnicas de controle racional das práticas e procedimentos persecutórios do Estado. Assim, a sua função precípua é funcionar como dique de contenção do poder punitivo, filtrando somente as práticas e procedimentos persecutórios que sejam estritamente constitucionais, convencionais, legais e racionais.

O Juiz criminal no Estado Democrático de Direito tem o papel de filtrar de modo implacável as pretensões, práticas e procedimentos persecutórios do Estado, impedindo aqueles que não sejam claramente constitucionais, convencionais, legais e racionais. Para desempenhar essa importante função o Magistrado dispõe da dogmática do Direito Processual Penal. ${ }^{4}$

Se, ao invés, tal julgador resolve se investir no papel de agente catalisador do poder punitivo, atuando como combatente da criminalidade econômico-financeira organizada e suprimindo garantias do acusado, ocorre grau tão intenso de degeneração estrutural do Direito Processual Penal que este se reduz a formas neoinquisitivas de autotutela do poder punitivo, que são características do Estado de Polícia.

Vale dizer: o sacrifício das garantias do acusado no altar da defesa social contra a criminalidade econômico-financeira organizada enseja verdadeiro simulacro neoinquisitivo de Processo Penal, o qual é instrumentalizado como meio de combate ao acusado. ${ }^{5}$

penal do inimigo, In: Revista Brasileira de Ciências Criminais, São Paulo, n. 59, pp. 223-259, mar./abr. 2006.

4 BATISTA, Nilo. A criminalização da advocacia, In: Revista de Estudos Criminais, Porto Alegre, n. 20, pp. 85-91, out./dez. 2005.

5 "El denominado proceso inquisitivo no fue $y$, obviamente, no puede ser, un verdadero proceso. Si éste se identifica como actus trium personarum, en el que ante un tercero imparcial comparecen dos partes parciales, situadas en pie de igualdad y con plena contradicción, y plantean un conflicto para que aquél lo solucione actuando el Derecho objetivo, algunos de los caracteres que hemos indicado como proprios del sistema inquisitivo llevan ineludiblemente a la conclusión de que ese sistema no puede permitir la existencia de un verdadero proceso. Proceso inqui- 
Assim, o enfoque deste estudo é circunscrito a apontar alguns aspectos característicos da investigação preliminar e do procedimento probatório na seara da criminalidade econômico-financeira, principalmente na dinâmica das práticas e procedimentos adotados pelas agências do poder punitivo no curso da persecução penal.

Para tanto, far-se-á imprescindível recorte epistemológico, excludente tanto das demais fases da persecução penal quanto de aspectos dogmáticos específicos de cada meio de investigação ou de prova individualmente considerado.

\section{Processo penal aplicado À CRIMINAlidade eConômico-Financeira ORGANIZADA: AUSÊNCIA DE AUTONOMIA CIENTÍFICA}

Antes de ingressar no ponto fulcral do presente estudo, cabe breve palavra acerca da problemática da suposta autonomia científica do Direito Processual Penal aplicado à criminalidade econômico-financeira organizada.

Em outras palavras: trata-se de saber se - à semelhança do que é defendido por abalizada corrente doutrinária na esfera do Direito Penal - seria possível falar-se em um Direito Processual Penal Econômico enquanto ramo do saber jurídico cientificamente autônomo com relação ao Direito Processual Penal aplicado à criminalidade de massas.

Questão preliminar seria saber se o modelo tradicional de Processo Penal é adequado às necessidades práticas da persecução da criminalidade econômico-financeira contemporânea, ou se é necessário criar subsistema processual penal específico para a persecução da sobredita criminalidade.

Daniel Pastor sustenta a inadequação desse modelo tradicional - vocacionado à persecução dos conflitos sociais de menor importância e baixa complexidade fática - e a consequente necessidade de reformulação estrutural do sistema de investigação preliminar e das funções processuais desempenhadas pelo Ministério Público.

sitivo se resuelve asi en una contradictio in terminis" (MONTERO AROCA, Juan. Principios del proceso penal: Una explicación basada en la razón, pp. 2829. Valencia: Tirant Lo Blanch: 1997). 
Assim, esse autor defende a criação subsistema processual penal específico para crimes econômico-financeiros, no qual haveria mitigação do princípio da oficialidade da ação penal.

Ou seja: o Ministério Público seria substituído, conforme o caso, por órgão da Administração Pública (dedicado à regulação do setor econômico respectivo, detecção e subsequente notícia da infração penal) ou entidade não governamental (voltada à defesa dos bens ou interesses coletivos afetados pelo crime), os quais são mais capacitados para preparar, formular e conduzir a imputação penal. ${ }^{6}$

Os juristas argentinos Gustavo Arocena e Fabian Balcarce, em instigante obra destinada a esboçar as bases da Teoria Geral do Processo Penal aplicado à criminalidade econômico-financeira, sustentam que tal ramo do saber jurídico já atingiu grau significativo de autonomia. ${ }^{7}$

Para tanto, eles acenam com três níveis distintos de autonomia: (i) legislativa: profusão de normas atinentes a crimes de natureza econômico-financeira, tratando quer de organização judiciária (v.g. Varas Criminais especializadas), quer de matéria processual propriamente dita; (ii) científica: conjunto de princípios próprios (v.g. especialização judicial; prova técnica; restrição da imediação no Juizo oral etc.); (iii) acadêmica: criação de programas de extensão e Pós-Graduação voltados para o ensino e pesquisa do Direito Penal Econômico e seus reflexos no campo processual. ${ }^{8}$

Tais autores arrolam diversos princípios que formarão as bases de uma Teoria Geral do Processo Penal Econômico, dentre os quais avultam os seguintes: (i) organicidade: necessidade de unificação dos critérios de política criminal atinentes ao tema do processo penal econômico; (ii) epistemologia diferenciada: existência de novos princípios, por vezes antagônicos em relação àqueles pertencentes ao Processo

6 PASTOR, Daniel. ¿Es conveniente la aplicación del proceso penal "convencional" a los delitos "no convencionales"? In: MAIER, Julio (Org.). Delitos no convencionales, pp. 269-301. Buenos Aires: Del Puerto, 1994.

7 AROCENA, Gustavo, BALCARCE, Fabián. Derecho penal económico procesal: Lineamientos para la construcción de una teoría general. Buenos Aires: Ediar, 2009.

8 AROCENA, Gustavo, BALCARCE. Op. cit., pp. 19 e ss. 
Penal tradicional; (iii) independência acadêmica: exigência de reformulação da matriz curricular jurídica, com a criação de disciplina específica dedicada à matéria em exame; (iv) regulação específica: necessidade de nova configuração do modelo processual penal, à luz dos novos matizes científicos trazidos pelo Direito Penal Econômico; (v) prova tecnocrática: prevalência do meio de prova pericial sobre o testemunhal; (vi) expansão da teoria da ação penal pública: condicionamento frequente da ação penal de conhecimento condenatória à instância administrativa etc. ${ }^{9}$

Nada obstante, o Direito Processual Penal incidente sobre a criminalidade em digressão ainda haure seu arcabouço de princípios, metodologia e objeto de estudo do seu ramo tradicional (aplicável à criminalidade de massas).

Portanto, nossa opinião é tendente à conclusão de que por ora inexiste grau de evolução acadêmica, científica e legislativa que justifique a autonomia do chamado Direito Processual Penal Econômico, em relação ao Processo Penal tradicional.

Essa constatação não impede a criação de subsistema processual penal específico para a criminalidade econômico-financeira, nem que a evolução científica do Direito Processual Penal futuramente permita atingir semelhante grau de autonomia.

De toda sorte, é absolutamente certa a assimetria ora existente entre a expansão do Direito Penal Econômico - notadamente quanto à profusão de leis instituindo novas figuras delitivas - e o subdesenvolvimento do Direito Processual Penal aplicável a essa crescente constelação de normas penais incriminadoras.

Portanto, o Processo Penal brasileiro remanesce até hoje carecedor de subsistema específico, contendo institutos e procedimentos adequados para a persecução e comprovação empírica das infrações penais de cariz econômico-financeiro.

Decerto há variegadas peculiaridades desse ramo do saber jurídico aplicado à criminalidade econômico-financeira organizada, não só nos planos dogmático, legislativo e normativo, como também na própria

9 AROCENA, Gustavo, BALCARCE. Op. cit., pp. 111 e ss. 
dinâmica das práticas e procedimentos persecutórios adotados pelo sistema de administração da justiça criminal no País (Law in action).

É o que se tentará demonstrar no item seguinte.

\section{Segue: Notas sobre a investigação e Prova}

Considerando que o tipo de criminalidade em digressão em regra se utiliza da estrutura societária de corporação de negócios, o iter investigativo do fato econômico-financeiro consiste em ampla devassa sobre os variegados setores que integram esse ente corporativo.

Assim, se busca apurar quais desses setores - e respectivos gestores responsáveis - tiveram participação nos fatos investigados, e não raro a apuração se espraia também para outras corporações intervenientes no fato (v.g. empresas coligadas; escritórios de contabilidade etc.).

A investigação preliminar nessas circunstâncias possui cariz altamente aflitivo e invasivo. Isso porque as próprias natureza e estrutura organizacional da empresa - composta de diversos setores operacionais, cada qual a cargo de um grupo distinto de funcionários - oferece terreno mais amplo e ramificado para a atividade investigativa policial.

Disso resulta verdadeira invasão estatal do negócio, o qual é submetido a uma espécie de estado de assédio, capaz de paralisar suas atividades empresariais.

Não raro a investigação preliminar é feita nos autos de procedimento amorfo, sem qualquer regulamentação legal (v.g. "procedimento de investigação criminal (PIC)" ou "procedimento criminal diverso (PCD)" do Ministério Público), ou exclusivamente nos autos de medidas cautelares que na prática funcionam como sucedâneas do inquérito policial (o qual é instaurado somente como formalidade para pretextar tais medidas, não contendo em seu bojo nenhum elemento informativo relevante).

As medidas em digressão têm natureza jurídica de meios de pesquisa ou investigação, porquanto são extraprocessuais, não contraditórias e protagonizadas por servidores públicos diversos dos sujeitos processuais penais, tendo como objetivo obter fontes materiais de prova. 
Via de consequência o meio de pesquisa ou prova não serve diretamente ao convencimento do julgador sobre o mérito da causa, e se for obtido por meios ilícitos é considerado prova inadmissível em Juízo. ${ }^{10}$

Manoel da Costa Andrade leciona que essas medidas - por ele chamadas de métodos ocultos de investigação - causaram verdadeira ruptura do paradigma processual penal haurido do ideário da Ilustração, calcado na sua estrutura acusatória e no estatuto de sujeito processual do acusado.

Suas consequências diretas são: (i) o esgarçamento das tradicionais garantias liberais-clássicas do Direito Processual Penal; (ii) a multiplicação, em termos quantitativos e de potencial invasivo, dos meios de restrição a direitos fundamentais; (iii) a oscilação do pêndulo político e legislativo na direção da tutela do poder punitivo e dos interesses sociais securitários. ${ }^{11}$

Mais especificamente, vislumbra-se tendência no sentido da policialização da investigação, havendo alargamento e hipertrofia dos poderes da polícia judiciária.

Ademais, também há o fenômeno da privatização de certos aspectos da investigação preliminar, havendo uso de particular como uma espécie de longa manus da autoridade policial, no exercício da atividade-fim desta última. ${ }^{12}$

10 GOMES FILHO, Antonio Magalhães. Notas sobre a terminologia da prova (reflexos sobre o processo penal brasileiro), In: YARSHELL, Flávio Luiz, MORAES, Maurício Zanoide (Orgs.). Estudos em homenagem à professora Ada Pellegrini Grinover, pp. 303-318. São Paulo: DPJ Editora, 2005. Sobre tais medidas, ver: CENTRO DE ESTUDOS JUDICIÁRIOS. Medidas de combate à criminalidade organizada e económico-financeira. Coimbra: Coimbra Editora, 2004; FONSECA-HERRERO, Marta Gómez de Liaño. Criminalidad organizada y medios extraordinarios de investigación. Madrid: Colex, 2004.

11 ANDRADE, Manuel da Costa. Métodos ocultos de investigação (Plädoyer para uma teoria geral), In: MONTE, Mário Ferreira e outros (Coords.). Que futuro para o direito processual penal? Simpósio em homenagem a Jorge de Figueiredo Dias, por ocasião dos 20 anos do Código de Processo Penal português, pp. 525-551. Coimbra: Coimbra Editora, 2009.

12 Para tanto, basta atentar para o procedimento técnico-operacional de interceptação de comunicações telefônicas via o sistema informatizado Guardião, o qual é protagonizado por pelo menos duas empresas priva- 
Por derradeiro, ocorre esmaecimento da fronteira que separa as funções de prevenção e repressão de infrações penais, deslocando-se o Processo Penal para a primeira. Vale dizer: há tendência de intervenção preventiva das agências que integram o poder punitivo, em detrimento da tradicional postura reativa. ${ }^{13}$

Quanto aos métodos em digressão propriamente ditos, suas principais características são as seguintes: (i) institucionalização, por força de sua regulamentação legal expressa ou aceitação com base em aplicação analógica de instituto congênere; (ii) generalização, pela sua expressão massificada (v.g. interceptação simultânea de uma dezena de linhas telefônicas, que implica interceptação das comunicações de centenas de pessoas via milhares de ligações). ${ }^{14}$

Os métodos ocultos de investigação consistem em gama heterogênea de institutos, abarcando as interceptações de comunicações telefônicas e telemáticas; busca e apreensão de mensagens de correio eletrônico (e-mails) armazenadas em servidor (busca e apreensão virtual); compartilhamento de dados de localização de aparelho telefônico celular; infiltração de agentes; interceptação ambiental domiciliar de conversas entre pessoas presentes etc. ${ }^{15}$

Já para Friedrich Dencker as principais características dos métodos ocultos de investigação são amplitude, segredo e ausência de âmbitos-tabu. ${ }^{16}$

Tal amplitude pode ser entendida em pelo menos duas acepções: (i) quanto à quantidade, tendo em vista que o catálogo previsto no artigo $3^{\circ}$ da Lei $n^{\circ}$. 12.850/13 na prática é meramente exemplificativo, não excluindo meios de investigação atípicos (v.g. pagamento de "verba secreta de informante" a particular pela Polícia Federal); (ii) no que tange às pessoas afetadas pela medida, que incluem não só o próprio investigado

das: a concessionária do serviço público de telefonia (da qual o "alvo" da medida é cliente) e a operadora desse sistema informatizado (a Dígitro Tecnologia LTDA.).

13 ANDRADE, Manuel da Costa. Op. cit., pp. 529-531.

14 ANDRADE, Manuel da Costa. Op. cit., pp. 531-532.

15 ANDRADE, Manuel da Costa. Op. cit., pp. 532-535.

16 DENCKER, Friedrich. Criminalidad organizada y procedimiento penal, In: Nueva Doctrina Penal, Buenos Aires, n. B, pp. 479-494, 1998. 
e eventuais coautores e partícipes, mas também terceiras pessoas que integram o círculo de relações sociais do primeiro grupo.

O segredo desse arsenal de medidas decorre do seu caráter dissimulado e sub-reptício, sendo oponível tanto ao próprio investigado quanto ao seu Defensor técnico (por se tratarem de medidas cautelares processadas inaudita altera parte, nos termos do artigo 282, § $3^{\circ}$, ab initio do Estatuto Processual Penal).

Por ausência de âmbitos-tabu se entende o efeito dessas medidas de suprimir diversas das tradicionais regras de proibição probatória características do Processo Penal democratizado.

Por exemplo, os direitos fundamentais do investigado: (i) à prestação estatal de informação sobre o seu direito ao silêncio (nemo tenetur se detegere); (ii) à inviolabilidade das suas comunicações pessoais ou telefônicas com seu Advogado, médico ou cônjuge etc. ${ }^{17}$

No País, se podem alinhavar algumas peculiaridades adicionais dos métodos ocultos de investigação: (i) grave déficit legislativo: há métodos atípicos, ou seja, sem procedimento probatório regulamentado em lei (v.g. interceptação ambiental domiciliar de conversas entre pessoas presentes), sem haver sequer meio de investigação típico cujo procedimento lhes possa ser aplicado, por analogia; (ii) procedimento técnico-operacional oculto: há grave omissão legislativa quanto ao procedimento técnico-operacional específico a ser adotado na efetivação da medida, que remanesce alheio ao conhecimento e controle do Juiz e das partes processuais (v.g. busca e apreensão de mensagens de correio eletrônico (e-mails) armazenadas em servidor); (iii) quebra da cadeia de custódia: como inexistem regulamentos e procedimentos administrativos acerca da cadeia de custódia há frequente ilicitude probatória, decorrente da

17 DENCKER, Friedrich. Op. cit., pp. 486-490. Em sentido semelhante: HASSEMER, Winfried. Processo penal e direitos fundamentais, In: PALMA, Maria Fernanda (Coord.). Jornadas de direito processual penal e direitos fundamentais, pp. 15-25. Coimbra: Almedina, 2004; PRADO, Geraldo. Da lei de controle do crime organizado: Crítica às técnicas de infiltração e escuta ambiental, In: WUNDERLICH, Alexandre (Org.). Escritos de direito e processo penal em homenagem ao professor Paulo Cláudio Tovo, pp. 125-137. Rio de Janeiro: Lumen Juris, 2002. 
adulteração ou perda das fontes materiais de prova obtidas (artigo 159, § $6^{\circ}$ do Código de Processo Penal). ${ }^{18}$

Todas essas características põem em causa a constitucionalidade material dos métodos em liça, à luz da garantia do due process of law e seu corolário da legalidade probatória.

No plano da estratégia policial, são comuns ações de forte caráter midiático e simbólico, em regra consistentes no cumprimento simultâneo de mandados judiciais (de busca e apreensão domiciliar, condução coercitiva, prisão temporária etc.) nos diversos endereços de conglomerado empresarial por dezenas de agentes (fazendários, policiais etc.), dotados de forte aparato bélico.

Tais ações policialescas tendem a ter denominações exóticas e acompanhamento em tempo real pelos mass media, além de ser sucedidas de ampla e imediata divulgação dos seus detalhes pelos órgãos de assessoria de imprensa - inclusive no que tange aos nomes completos dos investigados.

Sua finalidade declarada é impedir a adulteração ou destruição de fontes de prova na posse dos investigados, mas suas consequências práticas para os quadros organizacionais são a difusão de sentimento de pavor e do conhecimento acerca da extensão e face mais cruenta do poder punitivo do Estado.

Além disso, não é incomum a paralização da própria atividade-fim do ente corporativo que sofre tais medidas extremas, devido à apreensão de grande volume de dados e documentos (contábeis; fiscais; mercantis etc.) - a vasta maioria dos quais é imprescindivel para a consecução do objeto social da empresa, porém inútil para as investigações policiais.

Outros possíveis efeitos colaterais são os seguintes: (i) divulgação indevida dos chamados segredos de empresa; (ii) danos significativos ao conceito empresarial e ao faturamento do ente, podendo haver rescisões de contratos de clientes e fornecedores; queda do valor

18 PRADO, Geraldo. Prova penal e sistema de controles epistêmicos: A quebra da cadeia de custódia das provas obtidas por métodos ocultos. São Paulo: Marcial Pons, 2014. 
de mercado das ações de companhias de capital aberto; demissão maciça de funcionários etc. ${ }^{19}$

Com relação à pessoa física do investigado, se constata que a estratégia persecutória na prática é voltada à obtenção de confissão ou delação (finalidade não declarada). ${ }^{20}$

Com efeito, a imposição simultânea de diversas coações sobre a liberdade, domicílio, família, patrimônio, dignidade, reputação etc. tem como principal objetivo exercer o maior grau possível de pressão sobre a pessoa do investigado e vencer sua resistência física e psicológica.

Assim, trata-se de procedimento inquisitivo puro, no qual o emprego de diversas medidas de coação patrimonial, pessoal e probatória ao mesmo tempo tem fim não cautelar: o de obter confissão e/ou acordo de delação premiada do objeto da investigação (o investigado). ${ }^{21}$

Não se pode ignorar que a prisão temporária, por admitir prorrogação do seu prazo "em caso de extrema e comprovada necessidade" (artigo $2^{\circ}$ da Lei no. 7.960/89), também integra essa estratégia de coação física e psicológica, podendo se prestar ao fim da extorsão de confissão ou delação premiada do investigado, sob a ameaça - explícita ou velada - de a autoridade policial requerer a sobredita prorrogação de prazo. ${ }^{22}$

19 AMODIO, Ennio. I reati economici nel prisma dell'accertamento processuale, In: Rivista Italiana di Diritto e Procedura Penale, Milano, v. 51, pp. 1.496-1.506, ott./dic. 2008.

20 NOBILI, Massimo. Associazioni mafiose, criminalità organizzata e sistema processuale, In: MOCCIA, Sergio (Org.). Criminalità organizzata e risposte ordinamentali, pp. 223-241. Napoli: Edizioni Scientifiche Italiane, 1999.

${ }^{21}$ Os acordos de delação premiada violam os princípios constitucionais da legalidade e moralidade da Administração Pública, além do conteúdo ético minimo do Estado, pois este cai em contradição normativa e compromete a legitimidade ético-jurídica do poder punitivo caso, a pretexto de aplicar este último, assegure a imunidade penal de criminosos confessos, em troca de informações (COUTINHO, Jacinto Nelson de Coutinho, CARVALHO, Edward Rocha de. Acordos de delação premiada e conteúdo ético mínimo do Estado, In: Revista de Estudos Criminais, Porto Alegre, n. 22, pp. 75-84, abr./jun. 2006).

22 MALAN, Diogo. Prisão temporária, In: MALAN, Diogo, MIRZA, Flávio (Coords.). Setenta anos do Código de Processo Penal brasileiro: Balanço e perspectivas de reforma, pp. 73-109. Rio de Janeiro: Lumen Juris, 2011. 
A coação incidente de forma indiscriminada sobre todos os ativos financeiros e bens do investigado também serve para impedir que ele receba assistência jurídica adequada, à míngua da liquidez e solvência imprescindíveis para contratar Defensor técnico particular razoavelmente qualificado.

$\mathrm{Na}$ expressão de Ennio Amodio, o procedimento é de banda larga abarcando a apuração de: (i) como se formou a vontade de colocar em marcha a atividade acoimada de delituosa; (ii) quem concorreu para a formação dessa vontade; (iii) em que medida o efetivo conhecimento do projeto criminoso correspondeu à repartição formal de funções do organograma da companhia. ${ }^{23}$

A sobredita amplitude enseja cadeia de investigados que entram e saem da investigação preliminar, até a formalização da acusação formal pelo Ministério Público. O efeito automático desse fenômeno é a exclusão de alguns investigados dessa imputação formal, quando o espectro investigativo original se revela excessivamente amplo.

Malgrado a sobredita irradiação da investigação preliminar para diversos setores da corporação de negócios torne este só o ambiente do empenho investigativo, o fenômeno da aglutinação enseja fusão entre as respectivas responsabilizações dos administradores e da própria pessoa coletiva.

Vale dizer: vislumbra-se tendência no sentido de o próprio ente corporativo sofrer sanções de cariz administrativo ou penal, ou efeitos patrimoniais da sentença condenatória, em decorrência de infração penal cometida pelos administradores.

$\mathrm{Na}$ Itália, por exemplo, o artigo $5^{\circ}$ do Decreto Legislativo $\mathrm{n}^{\circ}$. 231/2001 instituiu responsabilidade administrativa do ente empresarial em decorrência de infração penal cometida pelo seu gestor, desde que ela seja praticada no interesse ou em benefício do primeiro. ${ }^{24}$

Outro fenômeno apontado pelo precitado autor peninsular é o do duplo binário.

23 AMODIO, Ennio. Op. cit., p. 1.500.

${ }^{24}$ AMODIO, Ennio. Op. cit., pp. 1.499-1.501. 
Trata-se de consequência direta da duplicação de investigações sobre o mesmo fato econômico-financeiro: uma na esfera da persecução penal e outra perante o órgão da Administração Pública responsável pelo controle, fiscalização e regulação dos entes corporativos que atuam naquele setor (v.g. Banco Central do Brasil; Comissão de Valores Mobiliários etc.).

Essa conjuntura cria uma assimetria de fato entre as partes processuais penais, hipertrofiando os poderes da acusação pública: esta última vê fortalecidos seus poderes na colheita de elementos informativos e provas, mercê da colaboração do órgão responsável pelo procedimento administrativo sancionador sobre os mesmos fatos.

Ademais disso, na fase judicial da persecução penal o órgão acusador pode contar com o servidor responsável pela condução do sobredito procedimento administrativo sancionador como fonte de prova testemunhal.

Daí a sensação do acusado de estar diante de dois acusadores, um dos quais é autorizado a depor em Juízo sob o compromisso legal de dizer a verdade, na qualidade de testemunha.

Para abordar as peculiaridades do ônus da prova na seara em digressão, é imprescindível breve exposição acerca do fenômeno da expansão do Direito Penal e de seus reflexos na estrutura das normas penais econômicas.

Como é cediço, o fenômeno da expansão do Direito Penal na Pós-Modernidade está relacionado a variegados fatores sociais, notadamente a globalização econômica; integração supranacional em blocos econômicos; revolução tecnológica etc.

Uma das principais consequências dessa expansão é o fenômeno da administrativização do Direito Penal Econômico.

Trata-se de ruptura paradigmática que envolve mutação da própria estrutura e do conteúdo material das normas penais incriminadoras. Em outras palavras: o Direito Penal passa a servir como instrumento de gestão de riscos de cariz estatístico, global ou sistêmico. Por conseguinte, ele perde qualquer traço distintivo do Direito Administrativo Sancionador, passando a desempenhar função idêntica a este último: ordenar determinados segmentos da atividade estatal, conforme determinada política de gestão setorial. 
Essa nova função enseja duas graves consequências, do ponto de vista do Estado Democrático de Direito: (i) a equiparação da estrutura normativa do ilícito penal ao administrativo, enquanto ato de mera desobediência à regulação de setores da atividade estatal, eticamente neutro e independente de ofensividade concreta ou imputabilidade a pessoa determinada; (ii) a incorporação pelo Direito Penal da flexibilização dos critérios de atribuição de responsabilidade característica do Direito Administrativo Sancionador.

Os dois principais vetores político-criminais que pautam essa mutação estão relacionados: (i) à introdução de novos objetos de tutela jurídico-penal; (ii) à antecipação da intervenção penal.

Nesse contexto há abandono do paradigma liberal-clássico de Direito Processual Penal, baseado na imputação de crimes de natureza material (ou de resultado), a exigir comprovação empirica em Juízo de relação causal entre conduta humana e dano a bem jurídico conceitualmente preciso e de titularidade individual.

Por razões de ordem pragmática ou utilitarista ora há nítida tendência à adoção de novo paradigma, consistente na imputação de crimes econômico-financeiros de cariz formal e de perigo presumido a bem jurídico conceitualmente impreciso e de titularidade coletiva - relacionado a políticas públicas e funções administrativas estatais de gestão, controle ou regulação de determinado setor da Economia (v.g. Ordem Econômica; regular funcionamento do Sistema Financeiro Nacional etc.). ${ }^{25}$

Tal conjuntura é agravada pela própria geometria normativa variável característica do Direito Penal Econômico, repleta de: (i) elementos normativos que remetem a conceitos altamente imprecisos e subjetivos (v.g. "gestão temerária de instituição financeira"); (ii) normas penais em branco complementadas pelo emaranhado cipoal de atos administrativos e normativos característico da cultura luso-romana cartorária e burocrática da Administração Pública, inexpugnável pelo cidadão comum (v.g. "sem licença ou autorização dos órgãos ambientais competentes, ou contrariando as normas legais e regulamentares pertinentes").

25 SILVA SÁNCHEZ, Jesús-María. La expansión del Derecho penal: Aspectos de la politica criminal en las sociedades postindustriales, pp. 131 e ss. 2. ed. Montevideo: Editorial B de f, 2008. 
Assim, é lícito concluir que a satisfação do ônus de provar o fato econômico-financeiro típico, ilícito e culpável pela parte acusadora é sobremaneira facilitada, à míngua da necessidade da demonstração empírica de: (i) tipicidade material da conduta do acusado; (ii) relação causal entre tal conduta e dano a bem jurídico conceitualmente preciso e específico; (iii) vitima individualizada. ${ }^{26}$

Outra consequência prática é que a refutação desses aspectos da imputação pela Defesa técnica do acusado constitui verdadeira probatio diabolica, porquanto é impossível a demonstração empírica da ausência de lesão ao bem jurídico-penal.

Assim, é lícito supor que a estrutura das normas penais incriminadoras na esfera econômico-financeira tem como principal raison d'être político-criminal a solução de problemas processuais penais, pela eliminação de circunstâncias elementares do tipo penal de difícil comprovação empírica em Juízo. ${ }^{27}$

De fato, já se fala de hodierna estratégia político-criminal voltada ao generalizado e maciço empobrecimento da tipicidade ("impoverimento della fattispecie"), cuja comprovação em Juízo se torna empiricamente impossível à míngua de determinação, materialidade e ofensividade da conduta incriminada - a qual é esvaziada de qualquer conteúdo essencial. ${ }^{28}$

Outra característica de nota é a primazia do meio de prova pericial sobre os demais, tratando-se da verdadeira rainha das provas (regina probatorum) do processo penal aplicado aos crimes econômico-financeiros.

Isso porque tal meio probatório permite a "decodificação" ou "tradução" de determinada operação mercantil, financeira, fiscal etc. -

${ }^{26}$ MALAN, Diogo. Bem jurídico tutelado pela Lei 7.492/86, In: Revista Brasileira de Ciências Criminais, São Paulo, n. 91, p. 367-391, jul./ago. 2011.

27 Nesse sentido: VOLK, Klaus, Criminalità economica: Problemi criminologici, politico-criminali e dommatici, In: Sistema penale e criminalità economica: I rapporti tra dommatica, politica criminale e processo, pp. 29-59. Napoli: Edizione Scientifiche Italiane, 1998.

D’ASCOLA, Vincenzo Nico. Impoverimento della fattispecie e responsabilità penale "senza prova": Strutture in transformazione del diritto e del processo penale, passim. Reggio Calabria, Iiriti Editore, 2008. 
em regra de alta complexidade e, portanto, incompreensível para o operador jurídico - pelo perito para o Juiz e as partes processuais.

Tal circunstância gera duplo efeito: (i) por um lado, ela facilita a atividade de valoração judicial da prova pericial, quando se manifestar tendência - ainda que inconsciente - de o Magistrado acatar na íntegra o juízo de valor sobre os fatos feito pelo experto, à míngua do cabedal de conhecimento técnico próprio que lhe permita questionar as premissas e conclusões periciais; (ii) por outro flanco, ela também dificulta sobremaneira eventual tentativa judicial de rejeição (artigo 182 do Código de Processo Penal) ou valoração crítica do laudo pericial oficial (especialmente quando inexistir contraprova pericial defensiva na forma de parecer técnico particular), pela natural dificuldade de o Juiz compreender o complexo fato econômico-financeiro imputado.

Circunstância agravante é o fato de que a prova pericial do fato econômico-financeiro em regra é produzida na fase da investigação preliminar, de forma unilateral, sendo submetida somente ao contraditório do acusado sobre o elemento de prova (contraddittorio sull'elemento di prova). Trata-se de mitigação dessa garantia, porquanto reduzida aos aspectos argumentativos do fenômeno probatório. ${ }^{29}$

No plano da valoração do resultado da prova, é lícito supor que o precitado fenômeno do duplo binário tende a fazer com que o Juiz se renda ao juízo de valor sobre o fato econômico-financeiro previamente feito em sede administrativo-sancionadora.

Isso devido a uma série de fatores, relacionados: (i) a razões de economia processual; (ii) à presunção de legitimidade dos atos administrativos sancionadores; (iii) a dificuldades técnicas de se viabilizar em Juízo uma reavaliação crítica do percurso lógico-probatório percorrido pela Administração Pública e acatado pela parte processual acusadora.

Logo, nos crimes econômico-financeiros há também significativa limitação prática (de fato) da liberdade de valoração probatória pelo Juiz criminal. ${ }^{30}$

29 UBERTIS, Giulio. Principi di procedura penale europea: Le regole del giusto processo, p. 57. Milano: Raffaello Cortina Editore, 2000.

30 AMODIO, Ennio. Op. cit., pp. 1.501-1.503. 
Com efeito, o caso penal em regra ostenta grau tão significativo de complexidade e sofisticação técnica que o torna compreensível somente pelos particulares que atuam profissionalmente naquele nicho da economia e servidores especializados no controle, fiscalização e regulação administrativa do sobredito nicho.

Assim, há um consequente esvaziamento da possibilidade de constatação empírica do caso no Juízo criminal. ${ }^{31}$

Além disso, na formação de seu convencimento sobre o fato econômico-financeiro imputado o Magistrado em regra não pode se valer das chamadas regras de experiência comum (artigo 335 do Estatuto Processual Civil).

Estas decorrem da convicção pessoal do Juiz - decorrente de sua formação acadêmica, cultural, intelectual e técnica, além da sua bagagem de vivências pessoais e profissionais - acerca daquilo normalmente acontece em determinado contexto das relações sociais.

Trata-se de versão personificada da cultura média, do senso comum ou da constelação de concepções que constituem o patrimônio cultural difuso do contexto espaço-temporal em que o julgador está inserido - sendo enunciada na forma de regras tendencialmente gerais. ${ }^{32}$

Com relação ao fato econômico-financeiro, contudo, o Juiz em regra não possui regras dessa natureza que possam socorrê-lo.

Para tanto, basta se atinar para o exemplo do ilícito penal praticado no contexto da gestão financeira cotidiana de grande conglomerado empresarial multinacional. Nesse caso, trata-se de realidade social completamente estranha ao conjunto de experiências pessoais e profissionais do Magistrado, inexistindo qualquer percepção pessoal acerca do que ordinariamente acontece.

Assim, na prática o julgador se torna dependente do juízo de valor pericial para poder formar seu convencimento sobre a culpa ou inocência do acusado.

${ }^{31}$ Nesse sentido: AROCENA, Gustavo, BALCARCE. Op. cit., p. 83.

32 TARUFFO, Michele. Considerazioni sulle massime d'esperienza, In: Rivista Trimestrale di Diritto e Procedura Civile, Milano, n. 02, pp. 551-569, giu. 2009. 
Vale dizer: há grau tão intenso de ingerência administrativa que ela é praticamente excludente de qualquer atividade jurisdicional de valoração do fato econômico-financeiro penalmente relevante.

O Poder Judiciário acaba atuando como espécie de peneira da atividade administrativa ao selecionar, a partir do produto final desta última, os subsídios necessários à adjudicação do caso penal. ${ }^{33}$

Portanto, na persecução penal de crimes econômico-financeiros há nítida potencialização de fenômenos denominados por Bernd Schünemann de efeito inércia (ou perseverança) e busca seletiva de informações.

Tal autor parte da teoria da dissonância cognitiva de Leon Festinger, segundo a qual o ser humano tende a procurar atingir relação de equilíbrio entre seu conhecimento e opiniões. $\mathrm{Na}$ hipótese da superveniência de dissonância cognitiva, portanto, o indivíduo tende a buscar reequilibrar seu próprio sistema cognitivo pela via da supressão das contradições. ${ }^{34}$

Assim, o fato de o Juiz tomar conhecimento do teor da investigação preliminar e emitir sucessivos juízos de valor sobre os fatos em julgamento (v.g. ao decretar tutelas cautelares; exercer juízo de admissibilidade positivo da peça inaugural acusatória; protagonizar a produção probatória em Juízo etc.) tende a acionar mecanismo de autoconfirmação das hipóteses judiciais.

Ou seja: o julgador, ao encampar como correta aquela versão dos fatos emergente da investigação preliminar, se torna incapaz de processar informações de forma adequada à valoração imparcial dos fatos - tendendo a superestimar sistematicamente os elementos probatórios que confirmam tal versão, e subestimar os demais (efeito inércia (ou perseverança)).

Por outro flanco, o Magistrado tende a procurar institivamente elementos probatórios que corroborem a hipótese previamente adotada,

${ }^{33}$ Nesse sentido: AROCENA, Gustavo, BALCARCE. Op. cit., pp. 29 e ss.

34 FESTINGER, Leon. A theory of cognitive dissonance. Stanford: Stanford University Press, 1957. 
ou mesmo aqueles que a desmintam, desde que sejam facilmente rejeitáveis pelo raciocínio judicial (busca seletiva de informaçôes). ${ }^{35}$

Também há risco de que a convicção do Juiz acerca do caso penal sofra perigosa influência de generalizações, estereótipos, mitos, preconceitos, ideias hauridas do senso comum teórico sobre a criminalidade econômico-financeira (everyday theories) etc.

Cuida-se de generalizações espúrias, porquanto consistem em deturpação do conceito de regras de experiência comum, destituída de qualquer embasamento científico ou empírico.

Nesse caso, não se sabe: (i) por quem a experiência foi protagonizada; (ii) quem originalmente formulou a regra geral invocada pelo Juiz; (iii) qual foi a base cognitiva para tal formulação; (iv) quantos casos concretos foram considerados para se urdir a sobredita regra; ( $v$ ) qual é a margem de erro na aplicação da regra em apreço. ${ }^{36}$

Por exemplo: decisões judiciais condenatórias por ilícito econômico-financeiro sem qualquer lastro em elementos de prova sobre a autoria delitiva, a pretexto do seguinte mito: a suposta onipresença e onisciência de todos os sócios-administradores de sociedade empresária com relação a qualquer acontecimento envolvendo esta última.

\section{Conclusão}

Ante todo o exposto, é lícito concluir que mesmo à míngua de autonomia científica decerto há significativas peculiaridades do Direito Processual Penal aplicado à criminalidade econômico-financeira organizada, não só nos planos dogmático, legislativo e normativo, como também na própria dinâmica das práticas e procedimentos persecutórios adotados pelo sistema de administração da justiça criminal (Law in action).

35 SCHÜNEMANN, Bernd. O Juiz como um terceiro manipulado no processo penal? In: Estudos de direito penal, direito processual penal e filosofia do direito, pp. 205-221. São Paulo: Marcial Pons, 2013.

36 TARUFFO, Michele. Op. cit., pp. 557 e ss. 
$\mathrm{Na}$ fase da investigação preliminar, as três principais características são: (i) uso maciço de métodos ocultos de investigação; (ii) procedimento inquisitivo puro; (iii) duplo binário.

O primeiro enseja supressão das garantias que integram o tradicional modelo liberal-clássico do Direito Processual Penal, resultando de oscilação do pêndulo político-criminal na direção da tutela do poder punitivo e dos interesses sociais securitários.

Mais concretamente, ocorrem os seguintes fenômenos: (i) policialização: há expansão dos poderes da polícia judiciária; (ii) privatização: há emprego de particular para desempenhar certas tarefas, agindo como longa manus da autoridade policial; (iii) prevenção: há intervenção preventiva das agências do poder punitivo, em vez da tradicional atuação repressiva.

Por procedimento inquisitivo puro se entende o uso integrado e simultâneo de diversas coações (pessoais, patrimoniais e probatórias) sobre o investigado e sua família, domicílio, ativos, bens, comunicações etc., para finalidade não cautelar.

Esta consiste na aplicação do maior grau possível de pressão sobre o investigado, com vistas a vencer sua resistência física e psicológica e obter confissão e/ou acordo de delação premiada do objeto da investigação.

O duplo binário, por sua vez, consiste no fenômeno da duplicação de investigações sobre o mesmo fato econômico-financeiro, criando-se assimetria de fato entre as partes processuais penais pela hipertrofia dos poderes do órgão acusador.

Ademais, como na fase judicial a parte acusadora pode contar com o presidente do procedimento administrativo sancionador como fonte de prova testemunhal, o acusado na prática tem que enfrentar dois acusadores, um dos quais ainda é autorizado a depor em Juízo sob o compromisso legal de dizer a verdade.

$\mathrm{Na}$ fase processual, as principais características são: (i) facilitação do ônus probatório subjetivo da parte acusadora; (ii) preponderância do meio de prova pericial; (iii) significativa limitação prática (de fato) da liberdade judicial de valoração probatória.

A primeira decorre das próprias características da figura delitiva econômico-financeira por excelência (crime formal e de perigo presumido a 
bem jurídico conceitualmente impreciso e de titularidade coletiva, relacionado a políticas públicas e funçôes administrativas estatais de gestão, controle ou regulação de determinado setor da Economia), que dispensa a parte acusadora da demonstração empírica em Juízo de: (i) tipicidade material da conduta do acusado; (ii) relação causal entre tal conduta e dano a bem jurídico conceitualmente preciso e específico; (iii) vitima individualizada.

Além disso, nessas circunstâncias a refutação da imputação pela Defesa técnica do acusado se consubstancia em verdadeira probatio diabolica, pois é rigorosamente impossível a demonstração empírica da ausência de lesão ao bem jurídico tutelado.

Outra característica é a relação de primazia do meio de prova pericial sobre os demais. Isso porque tal meio permite a "decodificação" ou "tradução" de determinada operação mercantil, financeira, fiscal etc. - em regra de alta complexidade e, portanto, incompreensível para o operador jurídico - pelo perito para o Juiz e as partes processuais.

Tal circunstância gera duplo efeito: (i) facilita a valoração judicial da prova pericial, pela tendência de o Magistrado acatar o juízo de valor do perito, à míngua do conhecimento técnico próprio imprescindível para criticar as premissas e conclusões periciais; (ii) dificulta a rejeição ou valoração crítica do laudo pericial oficial, pela dificuldade de o Juiz compreender todas as complexas nuanças do fato econômico-financeiro imputado.

Noutro giro, a limitação prática (de fato) da liberdade judicial de valoração probatória é decorrente do sobredito fenômeno do duplo binário.

Com efeito, fatores relacionados à: (i) economia processual; (ii) presunção de legitimidade dos atos administrativos sancionadores; (iii) dificuldade técnica de reavaliação crítica do percurso lógico-probatório percorrido pela Administração Pública, somados, tendem a forçar o Juiz a encampar o juízo de valor sobre o fato econômico-financeiro feito em sede administrativo-sancionadora.

Tal conjuntura é agravada pela inexistência de regras de experiência comum que possam auxiliar o Magistrado na valoração do fato econômico-financeiro, ante o cariz complexo e hermético deste último.

Destarte, é pertinente o debate político-criminal acerca da necessidade da criação de subsistema processual penal específico voltado 
à criminalidade econômico-financeira organizada, em razão de todas as precitadas peculiaridades desta última.

Não obstante, ainda mais importante do que debater a sobredita criação é definir qual é o tipo de diversificação sistêmica processual penal tolerável, à luz dos valores que informam o Estado Democrático de Direito - tema que infelizmente foge ao objeto do presente estudo.

Indiscutivel é que essa diferenciação não pode, à luz de qualquer concepção civilizada acerca do devido processo penal, ser feita à custa do sacrifício das garantias que integram o direito ao julgamento justo (fair trial), previstas na Constituição da República e no sistema internacional de Direitos Humanos. ${ }^{37}$

\section{Bibliografia}

AMODIO, Ennio. I reati economici nel prisma dell'accertamento processuale, In: Rivista Italiana di Diritto e Procedura Penale, Milano, v. 51, pp. 1.496-1.506, ott./dic. 2008.

ANDRADE, Manuel da Costa. Métodos ocultos de investigação (Plädoyer para uma teoria geral), In: MONTE, Mário Ferreira e outros (Coords.). Que futuro para o direito processual penal? Simpósio em homenagem a Jorge de Figueiredo Dias, por ocasião dos 20 anos do Código de Processo Penal português, pp. 525-551. Coimbra: Coimbra Editora, 2009.

AROCENA, Gustavo, BALCARCE, Fabián. Derecho penal económico procesal: Lineamientos para la construcción de una teoría general. Buenos Aires: Ediar, 2009.

BATISTA, Nilo. A criminalização da advocacia, In: Revista de Estudos Criminais, Porto Alegre, n. 20, pp. 85-91, out./dez. 2005.

37 Nesse sentido: GREVI, Vittorio. Nuovo codice di procedura penale e processi di criminalità organizzatta: Un primo bilancio, In: GREVI, Vittorio (Org.). Processo penale e criminalità organizzata, pp. 03-42. Bari: Laterza, 1993; LATANZI, Giorgio. Sui principi e sulla realtà del processo penale, In: Oralità e contraddittorio nei processi di criminalità organizzata, pp. 157-166. Milano: Giuffrè, 1999. 
BECK, Francis Rafael. Perspectivas de controle ao crime organizado e critica à flexibilização de garantias. São Paulo: IBCCRIM, 2004.

CENTRO DE ESTUDOS JUDICIÁRIOS. Medidas de combate à criminalidade organizada e económico-financeira. Coimbra: Coimbra Editora, 2004.

COUTINHO, Jacinto Nelson de Coutinho, CARVALHO, Edward Rocha de. Acordos de delação premiada e conteúdo ético mínimo do Estado, In: Revista de Estudos Criminais, Porto Alegre, n. 22, pp. 75-84, abr./jun. 2006.

D’ASCOLA, Vincenzo Nico. Impoverimento della fattispecie e responsabilità penale "senza prova": Strutture in transformazione del diritto e del processo penale. Reggio Calabria, Iiriti Editore, 2008.

DENCKER, Friedrich. Criminalidad organizada y procedimiento penal, In: Nueva Doctrina Penal, Buenos Aires, n. B, pp. 479-494, 1998.

FESTINGER, Leon. A theory of cognitive dissonance. Stanford: Stanford University Press, 1957.

FIGUEIREDO DIAS, Jorge de. O novo código de processo penal, In: Separata do Boletim do Ministério da Justiça, Lisboa, n. 369, pp. 05-23, 1987.

FONSECA-HERRERO, Marta Gómez de Liaño. Criminalidad organizada y medios extraordinarios de investigación. Madrid: Colex, 2004.

GIACOMOLLI, Nereu José. A garantia do devido processo legal e a criminalidade organizada, In: Revista de Estudos Criminais, Porto Alegre, n. 14, pp. 113-121, 2004.

GOMES FILHO, Antonio Magalhães. Notas sobre a terminologia da prova (reflexos sobre o processo penal brasileiro), In: YARSHELL, Flávio Luiz, MORAES, Maurício Zanoide (Orgs.). Estudos em homenagem à professora Ada Pellegrini Grinover, pp. 303-318. São Paulo: DPJ Editora, 2005.

O crime organizado e as garantias processuais, In: Boletim do Instituto Brasileiro de Ciências Criminais, São Paulo, n. 21, p. 08, set. 1994.

Também em matéria processual provoca inquietação a Lei Anti-Crime Organizado, In: Boletim do Instituto Brasileiro de Ciências Criminais, São Paulo, n. 13, p. 01, fev. 1994.

GREVI, Vittorio. Nuovo codice di procedura penale e processi di criminalità organizzatta: Un primo bilancio, In: GREVI, Vittorio (Org.). Processo penale e criminalità organizzata, pp. 03-42. Bari: Laterza, 1993. 
HASSEMER, Winfried. Processo penal e direitos fundamentais, In: PALMA, Maria Fernanda (Coord.). Jornadas de direito processual penal e direitos fundamentais, pp. 15-25. Coimbra: Almedina, 2004.

LATANZI, Giorgio. Sui principi e sulla realtà del processo penale, In: Oralità e contraddittorio nei processi di criminalità organizzata, pp. 157-166. Milano: Giuffrè, 1999.

MALAN, Diogo. Prisão temporária, In: MALAN, Diogo, MIRZA, Flávio (Coords.). Setenta anos do Código de Processo Penal brasileiro: Balanço e perspectivas de reforma, pp. 73-109. Rio de Janeiro: Lumen Juris, 2011.

. Bem jurídico tutelado pela Lei 7.492/86, In: Revista Brasileira de Ciências Criminais, São Paulo, n. 91, p. 367-391, jul./ago. 2011.

. Processo penal do inimigo, In: Revista Brasileira de Ciências Criminais, São Paulo, n. 59, pp. 223-259, mar./abr. 2006.

MONTERO AROCA, Juan. Principios del proceso penal: Una explicación basada en la razón. Valencia: Tirant Lo Blanch: 1997.

NOBILI, Massimo. Associazioni mafiose, criminalità organizzata e sistema processuale, In: MOCCIA, Sergio (Org.). Criminalità organizzata e risposte ordinamentali, pp. 223-241. Napoli: Edizioni Scientifiche Italiane, 1999.

PASTOR, Daniel. ¿Es conveniente la aplicación del proceso penal "convencional" a los delitos "no convencionales"? In: MAIER, Julio (Org.). Delitos no convencionales, pp. 269-301. Buenos Aires: Del Puerto, 1994.

PRADO, Geraldo. Prova penal e sistema de controles epistêmicos: A quebra da cadeia de custódia das provas obtidas por métodos ocultos. São Paulo: Marcial Pons, 2014.

. Da lei de controle do crime organizado: Crítica às técnicas de infiltração e escuta ambiental, In: WUNDERLICH, Alexandre (Org.). Escritos de direito e processo penal em homenagem ao professor Paulo Cláudio Tovo, pp. 125-137. Rio de Janeiro: Lumen Juris, 2002.

SCHÜNEMANN, Bernd. O Juiz como um terceiro manipulado no processo penal? In: Estudos de direito penal, direito processual penal e filosof ia do direito, pp. 205-221. São Paulo: Marcial Pons, 2013.

SILVA SÁNCHEZ, Jesús-María. La expansión del Derecho penal: Aspectos de la politica criminal en las sociedades postindustriales. 2. ed. Montevideo: Editorial B de f, 2008. 
TARUFFO, Michele. Considerazioni sulle massime d'esperienza, In: Rivista Trimestrale di Diritto e Procedura Civile, Milano, n. 02, pp. 551-569, giu. 2009.

UBERTIS, Giulio. Principi di procedura penale europea: Le regole del giusto processo. Milano: Raffaello Cortina Editore, 2000.

VOLK, Klaus, Criminalità economica: Problemi criminologici, politicocriminali e dommatici, In: Sistema penale e criminalità economica: I rapporti tra dommatica, politica criminale e processo, pp. 29-59. Napoli: Edizione Scientifiche Italiane, 1998.

COMO CITAR ESTE ARTIGO:

MALAN, Diogo. Notas sobre a investigação e prova da criminalidade econômico-financeira organizada. Revista Brasileira de Direito Processual Penal, Porto Alegre, vol. 2, n. 1, p. 213 - 238, 2016. http://dx.doi.org/10.22197/rbdpp.v2i1.22 